\title{
Innovation versus science?
}

\author{
Harder economic times will force governments to ask tough questions about their investments in research.
}

$\int^{p}$ cience and science funding have enjoyed a good run over the past 20 years or so. During the unusually long economic boom after the end of the cold war, governments of all political stripes have accepted the argument that it is in their interest to support 'the best science.' Something like a global consensus has emerged on the value of curiosity-driven, basic research. The predominant argument behind this consensus has been the belief that excellent science - of whatever discipline - is likely to spur innovation, which will in turn foster economic growth.

At the same time, direct government sponsorship of technology development has fallen out of vogue. Considerable expenditure continues, of course, and if the military sphere is included, it still dwarfs the resources devoted to basic science. But the idea of explicit state support for the development of drugs or circuit boards or civilian airliners has been pretty well driven off the table. There has been an assumption - even in comparatively centrist nations such as France and Japan - that governments aren't good at 'picking winners'.

This particular era of science and technology policy may now be drawing to a close. Even before last week's juddering stock markets sparked talk about a possible US, or even global, recession, policymakers in industrialized countries were watching the flight of much industrial production to China and India with intensifying alarm.

As a result, the word 'competitiveness' is back on the agenda, particularly in the United States. When political leaders look at research budgets in the light of competitiveness, they are always prone to be more drawn to the direct support of innovation through technology programmes, than to its indirect support, through basic science. As a result, they may start asking questions that are inherently difficult for scientists to answer, such as, what will be the economic spin-off from this work? What are we getting for our money?

These questions are currently being posed most directly in the United Kingdom, where the research councils, which support most university science, seem to be undergoing a subtle change of direction. Some scientist groups are already nervous about a paper, "Increasing the economic impact of the research councils", that was published in January by the councils' steering group.

There is a risk that this process could result in perceived economic relevance displacing scientific merit, to a significant extent, as the determining factor in the selection of research-council grants. Before that happens, it would be reassuring if the leaders of the research councils emphatically reiterated that their primary function is to promote scientific excellence - and that they will best support Britain's national interests, economic and otherwise, by doing exactly that.

A similar trend is beginning to emerge in the United States. The competitiveness legislation passed by Congress and signed into law on 9 August is positive for science it lays heavy emphasis on supporting basic research in mathematics, the physical sciences and engineering. Yet it is by no means certain that this approach will be reflected in the annual budget process. The Democrats, who now control both houses of Congress, have tradition-

"Scientists should resist the demand to compete on the basis of specious metrics constructed as surrogates for economic impact."

ally favoured technology programmes, sometimes over scientific ones, and that pattern could resume as fears about national competitiveness become more acute.

The argument will then be made for different scientific programmes to 'prove themselves' in answer to the taxpayers' question: what have you done for us lately? It is important, in such an environment, for scientists to hold their nerve. In particular, they should resist the inevitable demand that they start to compete with each other on the basis of specious metrics that bureaucrats, given half a chance, will construct as surrogates for economic impact.

Straitened economic circumstances, whenever they arrive, will mean straitened times for science: that much the research community must be ready to accept. It can also anticipate attempts to cut and splice the pie on the basis of ungrounded expectations that some disciplines will yield economic dividends, and others won't. Researchers have at least two weapons that they should keep well honed: a compelling historical narrative showing the unpredictable paths from science across all disciplines to economic and other benefits; and a demonstration that those best-placed to innovate on the basis of science - and, in turn, to stimulate scientific ideas - are well set up to do so.

\section{Indentured labour}

\section{The deal at the foot of the scientific totem pole remains a raw one.}

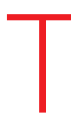
he Federation of American Societies for Experimental Biology (FASEB) has just released a report on the career trajectories of young life scientists in the United States (see page 848). It is likely to give pause to some of those currently considering graduate training as a route to a career in the academic life sciences.

The survey finds that over two decades the number of academically employed life scientists in tenured or tenure-track positions has remained stuck at about 30,000, while the number of doctoral degrees awarded in the life sciences has doubled. Thus the proportion of postdocs actually reaching tenured or tenure-track positions has dropped from nearly $45 \%$ in the early 1980 s, to just below $30 \%$.

The data also reveal a hard-to-reach career getting farther out of reach. The age at which the average $\mathrm{PhD}$ holder receives his or her first full National Institutes of Health grant has risen from 34 in 1970 